\title{
Russian Folklore as a Poetics of Inference: (based on material from the fairytale by Leonid Filatov "Fedot the Musketeer, a Brave Lad")
}

\author{
Innara A. Guseinova ${ }^{a *}$ \\ and William C. Brumfield ${ }^{\mathrm{b} *}$ \\ a Moscow State Linguistic University \\ 38 Ostozhenka Str., Moscow, 119034, Russia \\ ${ }^{b}$ Tulane University \\ New Orleans, Louisiana, USA
}

Received 14.05.2016, received in revised form 07.07.2016, accepted 20.08.2016

The present article examines Russian folklore from the position of dynamic linguistics at the intersection of semiotic and discourse theories. Russian folklore is treated as a semiotic code facilitating the unfolding of discourse in time and space, simultaneously ensuring the transmission of cultural and literary traditions and the consolidation of various ethno-social entities. Our analysis of the poetics of inference is conducted on the basis of material from the contemporary Russian tale, replete with ambiguity that can be understood through the emotional and intellectual efforts of the reader. Knowledge of the global context, of historical facts and realia provide the reader with the possibility, on the one hand, to delve into folklore traditions, and, on the other hand, to grasp the spiritual and material culture of the Russian people - the bearer of the folkloric element.

Keywords: folklore, dynamic linguistics, poetics of inference, tale, genre, historic event, poetic word, stereotype, value judgment.

DOI: 10.17516/1997-1370-2016-9-9-2223-2230.

Research area: theory and history of culture.

At the present time Russian folklore is experiencing a sort of "renaissance". Folklore motifs are widely represented in contemporary Russian fashion, Russian folk dances performed in folk costumes are extremely popular, the playing of national instruments (balalaika, accordion, wooden spoons, etc.). The internet is alive with materials referring to folklore motifs - student anecdotes, soldiers' humor, office humor and so forth. The facts enumerated above testify to the strength of national traditions, performing as a distinctive instrument for the consolidation of various social strata represented in the Russian language national-cultural confraternity.

We will remind that the term "folklore" (cf. Russian "folk wisdom") was introduced into

(C) Siberian Federal University. All rights reserved

* Corresponding author E-mail address: ginnap@mail.ru; william.brumfield@gmail.com 
scholarly use by the English scholar William James Thoms in 1846. It is commonly accepted that this concept embraces a people's spiritual as well as material culture, including folk crafts such as wood carving, blacksmithing, embroidery, weaving, etc., as well as dances, music, beliefs and rituals that are familiar to and observed by the majority of the members of an ethnosocial group. There exists a series of definitions of the term, a fact that bears witness to the pluralism of opinions among scholars occupied with the study of folklore and the traditions connected to it. However, it is possible to identify two tendencies in the use of the given term - broad and narrow. A broad understanding of folklore includes the collective creative activity of one or another people that reflects its quotidian and spiritual sphere in the most varied manifestations - from folk songs and dances to objects of decorative and applied arts. A narrow understanding of folklore is devoted to its interpretation in regard to oral creativity and is treated as "verbal folk creativity."

Folklore is distinguished by genre diversity. Folkloric works can encompass folk poetry, choral song, family legend, work song, ritual song, mythological story, incantation, the tale, the epic, religious verse, historical song, ditties, etc. An important trait of folklore is its collective character, in other words, as a collective art it does not have a concrete author but is disseminated by its bearer - the collective. As soon as an author appears for a work of folklore, it immediately acquires a specific genre form.

We will now examine how Leonid Alekseevich Filatov ${ }^{2}$ succeeded - with the aid of which lingual resources - in using folklore motifs as a base for creating the tale "“"Fedot the Musketeer, a Brave Lad".3

We will note first of all the use of vernacular lingual forms that have gone out of use (the archaic) and the use of speech markers [deformations], for example, entom for etom; none for nyne; $\underline{k u d y}$ for kuda; agromadnyi for gromadnyi, etc. Not infrequently one can take these for a misprint; however, it seems to us appropriate here to summon the statement of Velimir Khlebnikov on the usefulness of the misprint: "You remember what freedom the misprint sometimes gives from the given world. Such a misprint ... suddenly gives meaning to the whole thing ... (V. Klebnikov, quoted in E. F. Kovtun, 2014, p. 90). In our view the use of such stylistic devices provides the reader with the possibility to immerse oneself in another atmosphere, to detach oneself from the details of reality, or, on the contrary, to discursively see the conditioned interconnectedness.

In Filatov's tale there is a presence of artifacts (a crock, a broom, a trunk, etc.) or there occur events familiar to all members of Russianspeaking society from folktales, magic tales, everyday stories and other tales - for example, animals that speak in human language. Having failed to get food for the tsar's table, Fedot intends to kill the dove Golubitsa, who, however, turns to him with the words: "You, Fedot, don't touch me / Not a farthing's gain in that ...." [ $[\mathrm{Tbl}$, Федот, меня не трожь, / Пользы в энтом ни на грош...] This circumstance produces an ineradicable impression on Fedot. "That birds should speak / in human tongue?" [Чтобы птицы говорили / Человечьим языком?] Тhe dove Golubitsa, as in traditional Russian folk tales, promises the main hero a change in his fate: "Fedot, don't go for crime, / Take me with you instead. / When you take me into the upper chamber / I will become your fate." [Не твори, Федот, разбой, / А возьми меня с собой. / Как внесешь меня в светелку / Стану я твоей судьбой.] Simultaneously Filatov immerses this folktale plot into the context of the everyday tale. Golubitsa: "I will sew, I will wash, I will boil, / I won't chide for slights and hurts / I will play to you on the violin/ and your bedbugs I will squash! 
... [ Буду шить, стирать, варить, / За обидь не корить, / И играть тебе на скрипке, / И клопов тебе морить!... ] (L. A. Filatov, p. 16).

The marvelous transformation typical for many tales - for example, the frog into the princess - occurs in the upper room of Fedot the Musketeer: "Look - in the middle of my little room instead of a dove stands a beautiful maiden, slender as a young tree! ... [Глядь средь горенки заместо той горлинки стоит красна девица, стройная, как деревие!...] (L. A. Filatov, p. 17).

We will remind that the tale under analysis is in verse, and a significant place within it is given to the poetic word. The "poetic word" is treated as a lexical entity that is used primarily in artistic literature. The given lexemes are characterized by a high degree of expressivity that is clearly marked in dictionaries as literary (high) lexicon. Recently, however, there has been noted a quite intensive use of poetic words in mass information media, in social, commercial and political advertising, which bears witness to the demand for words perceived by the mass recipient as something new, fresh and unworn. Poetic works of contemporary literature are at present in extreme demand by virtue of a series of circumstances.

In the first place, the growing interest of scholars is conditioned to a large degree by the functions of the poetic text, directed toward the implementation of a pragmatic impact realized in the form of aphoristic formulae, slogans, mottos, etc.

In the second place, the poetic (expressive) word, applied in a cultural-historical or sociopolitical context, gives rise to a series of associations consonant with the moods of the mass recipient or separate target audiences.

In the third place, the expressive word is convergent, i.e. it facilitates the convergence and consolidation of society's various socially significant forces.
In the fourth place, the poetic text offers the possibility to examine the human cognitive system not only as a structure for processing and preserving a certain volume of knowledge, but also as a structure reflecting by various language means or by other semiotic codes the way in which humans see the world and treat events and phenomena that occur in the surrounding reality.

In the context of the preceding, a question arises concerning the attribution of one or another word to the class of the poetic. In the given case we subscribe to the views of contemporary cognitive scholars who propose that "in a language system the cognitive function is most fully expressed by units of a lexical level - lexemes and phraseologisms. Each appropriated lexical unit signifies a quantum of information about the world." (A. K. Kiklevich, 2014, p.74). In this manner any word submerged in definite culturalhistorical conditions is capable of fulfilling a poetic function.

Thus the artistic text has appellations to precedent phenomena, to "signs (words, utterances, texts), concepts, phenomena, subjects (including persons - so-called "heroes") that are well known to the representatives of a given culture, that reflect important aspects of reality, that are renewed in the spiritual (in particular, the spoken) activity of the members of a given social group [association]."

In the opinion of contemporary cognitive scholars the artistic text actualizes in the memory of representatives of a definite lingo-cultural social entity the recognizable categories that are key for a given ethnosocial group. Thus in the tale that we are analyzing, "Fedot the Musketeer, a Brave Lad", the following can be related to key recognizable categories: first of all, the heroes of a given tale, for example, Skomorokh (the minstrel), the Tsar, Baba-Yaga, Wife Marusya, Fedot the Musketeer himself, the brave lads, et al. To each of these heroes are attributed definite 
personality traits or psychological characteristics, professional skills. Thus for example Skomorokh fulfills the function of entertainer - he amuses the guests, jokes, creates a festive atmosphere. Fedot the Musketeer, the brave lad, is a person who solves various problems and can deal with anything. The foreign guests are also endowed with definite attributes, not always positive: "One from Sweden, another from Greece, a third from Hawaii - and get them all some chow! For one, lobster; for another, calamari, for a third, sardines - but only one fetcher! [Один из Швеции, другой из Грещии, третий с Гавайи всем жрать подавай! Одному - омаров, другому - кальмаров, третьему - сардин, а добытчик один!] (L. A. Filatov, p. 14). The tsar is presented as a whip cracker - "The tsar looks like a morel, a knob with a fist, and there is a huge amount of meanness in him." [Царь на вид сморчок, башка с кулачок, а злобности в емагромадный объем.] (L. A. Filatov, p. 14)

The author's judgments, expressed in the work with the help of a pejorative lexicon (cf. сморчок, кулачок - morel mushroom, fist), vernacular words (cf. башка - knob, noggin), as well as a deliberate imitation of folk speech (cf. 8 ем; агромадный) imparts to the text a folkloric character and simultaneously saturates it with satire, humor, not infrequently malicious irony, all facilitated by a mixture of styles or speech registers (cf. агромадный объем).

Various stereotypes can also come forth in the role of cognitive categories. In the opinion of A. K. Kiklevich: "stereotypes represent in the main categories of everyday behavior, when a detailed analysis of ongoing events is not required." (A. K. Kiklevich, 2014, p. 305). The aforementioned tale describes the main heroes' typical behavior, couched in Russian language folkloric motifs. Thus, the Tsar sends the Peasant [muzhik], in our case Fedot the Musketeer, on searches for food for a foreign guest, relying on the peasant's boldness, enterprise, and ability to solve the most diverse prosaic tasks, cf: To us for morning soup / Came the English ambassador, / But we had in the house snacks / Half a crust of bread and a bone [ К нам на утренний рассол / Прибыл аглиикий посол, / А у нас в дому закуски / Полгорбушки да мосол...] (L. A. Filatov, p. 14)

Fedot the Musketeer is threatened with execution for not fulfilling the commands, cf. "You can't do it - who's to blame? / I should execute you / It's a state affair / Do you get the gist? .... [Не смогешь - кого винить? / Я должон тебя казнить. / Государственное дело / Ты улавливаешь нить?... ] (L. A. Filatov, p. 15) The abuse of power, the desire to place blame on another, less significant and defenseless person is taken out of a global context by way of a juxtaposition of folkloric motifs (Tsar, a rich, powerful despot; Fedot, fast-thinking, hard-working peasant son) and facts mentioned in the tale of L. Filatov, cf. (Fedot): "After all, I don't drink tea from a bast shoe / I'll figure out what's what ..." [Чай, не лаптем щчи хлебаю, / Сображаю, что к чему...] (L. A. Filatov, p. 15)

The distribution of gender roles is also stereotypical in the analyzed tale: Fedot goes to serve the Tsar, while Marusia, Fedot's wife, busies herself around the house and takes care of things. Also important is the assessment of intellectual possibilities, both of Fedot and Marusia. In this regard it is emphasized that Marusia enters into the pleiade of fairy-tale heroines - Vasila the Beautiful, Vasilisa the Wise - capable of rendering help to their betrothed, husband, brother, suitor, et al. in a complicated, critical situation. For example, the Tsar places before Fedot the task of organizing a feast without considering the complexity of fulfilling the given mission. The following passage should be seen in the context of the 1980s and 90s. In this period of contemporary history, one could observe a very intense economic crisis, expressed in the 
presence of empty shelves in grocery stores. However, this did not prevent people even in those years from organizing festive dinners and getting items that were in short supply. Primarily women took upon themselves the basic work of getting these hard-to-find food items by using their contacts, connections, charm and other possibilities. For this reason Fedot's wife Marusia finds the solution in this tale: "Don't pout and don't whine! / There will be a table and there will be wild fowl! / So, stand before me, Teet Kuzmich and Frol Fomich! / (Marusia claps her hands - there appear two lads) / You got my order / Fulfill it now! (the Lads): "Have no doubts / This is not the first time! ...” (L. A. Filatov, p. 19) [« Маруся: Не кручинься и не хнычь! / Будет стол и будет дичь! / Ну ко станьте предо мною, Тит Кузьмич и Фрол Фомич! / (Марусяхлопает в ладоши - появляются два дюжих молодиа) / Коли поняли приказ / Выполняйте сей же час!; Молодцы: Не извольте сумлеваться, / Чай, оно не в первый раз!...» ]

The Tsar's dream is also stereotypical-to give his tsarevna-daughter's hand in a favorable marriage. Cf. Tsar: "Love is in truth evil, / So you'll love an ambassador / And also along the way help me improve / commercial affairs" (L. A. Filatov, p. 24) [«Коль любовь и вправду зла, / Дак полюбишь и посла. / А попутно мне поправишь / И торговые дела»]. The Tsar dreams of finding a rich suitor, despite shortcomings in his daughter's appearance and upbringing: "Tsar: The girl's grown up / Skinny as half an oar / Here's a tough one, how to marry off / Our queenie to an ambassador! ....» (L. A. Filatov, p. 21) [«Царь: Девка эвон подросла, / А тошуа, как полвесла! / Вот и мыслю, как бы выдать / Нашу кралю за посла!] «... Where to find a husband for the tsarevna? ... There's not a host of suitors! (L. A. Filatov, p. 23) [... Где иаревне мужа брать? ... Женихов у ей не рать! »] The comic in the given excerpt unquestionably originates in a play of words based on the consonance of two lexical units used in the genitive case («posla - kozla»\} that require a knowledge of the well-known, extremely widespread Russian saying «liubov' zla - poliubish' i kozla» (Love is evil, you will love a goat [i.e. an idiot]).

For the realization of his goal - to give his daughter in marriage - the Tsar invites as his guests suitors from various lands. In order to judge the merits of the potential suitors the Tsar tries to conduct with them a social conversation without knowing anything, as often happens in such situations. The absurdity of the Tsar's words are counterposed to the stereotypical perception of Russian reality by the foreign suitors, as is seen in an example of the dialog of the Tsar with the English emissary: «1) Tsar: Onterest is stimulated / By your technical progress: how do you over there sow rutabaga / With the skin or without? // Ambassador: «Yes!» 2) Tsar: Onterest is stimulated / By your educutional progress / How do you over there drink cacuo / With sugaries or without? ... // Ambassador: «Yes!» 3) Tsar: Onterest is stimulated / by another here query / How do your dames walk around / In pantaloons or without? // Ambassador: «Yes!» (L. A. Filatov, p. 20) [Царь: Bызыввает антирес / Ваш технический прогресс: Как у вас там сеют брюкву / С кожурою али без?... // Посол: Йес!; 2) Царь: Вызывает антирес / Ваш питательный прочесс: / Как у вас там пьют какаву / С сахарином али без?... // Посол: Йес!; 3) Царь: Вызыьвает антирес / И такой ишо разрез: / Как у вас там ходют бабы /В панталонах али без? // Посол: Йес!»] From the examples introduced above it follows that the representatives of English culture fulfilling their diplomatic activity in Russia do not know Russian. There are several explanations for this, but we suggest that behind the aforementioned dialog stands a definite stereotype of the rather haughty relation of the British to representatives 
of another culture. This situation is given more depth in the lines of Nanny, who sees the shortcomings of the foreign suitors: avarice, gluttony, stinginess and other shortcomings. In the process she bestows on them unflattering characteristics. cf. «Has a proud look - 'me' and more 'me' / and gluttonous as a pig / Give him a straw and he'll eat a straw, / An alien, not one's own!...» (L. A. Filatov, p. 23) [«С виду гордыц «я-a» да «я-a», / А прожорлив, как свинья, / Дай солому - съест солому,/ Чай, чужая, не своя!...»] And she does not neglect attention to shortcomings in appearance, cf. «Just look at his face / His ears are askew, a ring in his nose / And skin pock-marked like a cuckoo's egg! ...» (L. A. Filatov, p. 55) [«Ты взгляни ему в лицо: / Уши врозь, в носу кольцо! / Да и кожа вся рябая, / Как кукушкино яйцо!...»] The judgmental lexicon, expressed with the help of a complex of stylistic means - the epithet «pock-marked,» the simile «like a cuckoo's egg,» as well as a direct description of shortcomings in appearance - "ears are askew" and the unusual for that period of time but now fashionable tendency for piercing, "a ring in his nose" - summon in the reader a sense of disgust on the one hand, and on the other hand draw a comic portrait of a suitor that is generally associated with a pleasant appearance, tidy clothes, etc.

A significant role in the process of conceptualization and decoding of the given meanings is played by inference (cf. E. S Kurbakova; A. K. Kiklevich et al.) - a procedure for extracting knowledge that requires an understanding of the broad context - historical, cultural, literary, social, political, economic, in other words, requiring the presence of encyclopedic knowledge.

Let us examine the following example in which Baba Yaga addresses Fedot: "Baba Yaga: Why you are not yourself, / Not ruddy, not lively! ... / Or like a Swede at Petersburg, or a Turk at
Moscow? ...” (L. A. Filatov, p. 27) [«Баба Яга: Ты чавой то сам не свой, / Не румяный, не живой!... / Али швед под Петербургом, Али турок под Москвой?...»] It is notable that in the given example Baba Yaga alludes to the inglorious defeat of both the Swedes ${ }^{4}$ and the Turks ${ }^{5}$ in wars with Russia. Let us examine another example in this aspect of inference, cf. Nanny: Despotism is not in fashion now / Democracy is on the move" (L. A. Filatov, p. 69). In our view the given excerpt should be examined in the context of the contemporary history of Russia. It is well known that in the 1990s the political situation before the collapse of the USSR and for a time afterwards was very tense. This time gave rise to a mass of competitors trying to manage politics of the state. In the midst of this a decisive factor was the choice of the people, who were then supporting Boris Yeltsin $^{6}$ and his team. One can also introduce other examples that bear witness, for example, to the epoch of total shortages. Cf. Fedot: "What am I to do? How will I be? ... / How to get out of my troubles? / The tsar ordered me to deliver / That which cannot be!...” (L. A. Filatov, p. 42) [Федот: «Что мне делать? Как мне быть?... / Как беду мою избыть? / Приказал мне ияарь доставить / То Чаво Не Может Быть!...»] We will remind that the word deficit is understood as "a shortage of food items and manufactured goods, a lack of time and labor resources, a deficiency and insufficiency of social services" (I. G. Zemtsov, p. 142). In this context the hero of the analyzed tale was compelled to set out in search of scarce goods while standing in endless lines without any hope of the success which he, however, achieves by virtue of his moral qualities.

Let us turn to another example from the tale, cf. Tsarevna: "If thou art power in Rassia, / Then rule Rassia to thy heart's content / But don't barge into my fate / And don't crawl into my love!" (L. A. Filatov, p. 23) [Царевна: «Коли ты в Расее власть, / Дак и правь Расеей всласть, / А в мою 
судьбу не суйся / И в любовь мою не влазь!»] At first glance the given excerpt bears witness to the daughter's emotional protest, yet an inferential approach allows us to draw deeper conclusions. Thus in Russia's history women possessing power played by no means the least role. Above all, there were tsaritsas to whose lot fell the conduct of wars, the implementation of reforms and taking responsible decisions in foreign and domestic politics, as well as the suppression of uprisings and rebellions: Anna Ioanovna (16931740), Catherine the Second (1729-1796) and others. In the above context one can attribute to the tsarevna historically determined strivings for freedom and independence possessed by royal figures who ruled Russia at various times.
Let us emphasize that our analysis of lingual means and the results of our research are not exhaustive; however, it seems to us appropriate to summarize certain of our observations:

The tale uses a very limited selection of lingual means, thus ensuring the folklore essence in the given work;

The depth of the tale is shaped by the inferential character of the poetics used in the give verse tale;

The hidden meaning becomes comprehensible as a result of inference - the workings of the reader's cognitive system both emotional and rational, which ensure an interpretation of the given work within the reality of the recent historical past.

Electronic resource: http://www.krugosvet.ru/ enc/kultura_i_obrazovanie/literatura/FOLKLOR.htm (accessed 2/20/2015)

2 Leonid Alekseevich Filatov (12/24/1946, Kazan; 10/26/2003, Moscow) - Soviet and Russian actor, director, poet, commentator, People's Artist of Russia (1996), laureate of Russian Federation State Prize in film and television, laureate of the "Triumph" Prize. (electronic resource: http://www.bestpeopleofrussia.ru/ persona/1733/bio - accessed 4/23/2015)

3 "Fedot the Musketeer, a Brave Lad" (Сказка 'Про Федота-стрельца, удалого молодца'), a tale in verse, is the best known work of Leonid Filatov. Written in 1985, it was first published in the journal Iunost' in 1986. The work immediately gained great popularity. The use of fairytale characters in combination with Filatov's vivid speechand sharp satirical comments facilitated the unprecedented success. The work's subject is traditional for many Russian folk talks: wishing to eliminate the musketeer and marry his spouse, the tsar thinks up various tests for the hero. The final test is the impossible task to go I don't know where and bring back I don't know what. The felicitous hero's solution of this riddle leads the tsar to the loss of his throne. The work's traditional leading characters - the Tsar, the Commandant (General in Filatov's work), Fedot the Musketeer, his Wife (Marusia), Baba Yaga, the Helper Lads (Teet Kuzmych and Frol Fomich), Shmat-Thinker (the Voice or That Which Cannot Be). In addition to the main characters of the fairytale source, Leonid Filatov introduces to the narrative the Tsarevna and the Nanny. As a result the work has been given many performances in various theaters in Russian and the CIS, and it has also been made as an animated film. (electronic resource: http://yandex.ru/search/?text=nро $\% 20$ федота-стрельца\%20удалого\%20 молодца\%20леонид \%20филатов \&clid=9582\&lr=213 - accessed 5/10/2015)

4 These words are presumably a general reference to Peter the Great's victory over Sweden in the Great Northern War. In 1703 Peter I defeated Swedish garrisons along the Neva River and began construction of the city of St. Petersburg, whose founding arose from the need to consolidate Russia's position on the Gulf of Finland. Understanding this consolidation of strength, the Swedish king Charles XII launched an invasion in January 1708 with the intent to destroy the Russian army and seize Moscow. The attempt failed (cf. the decisive Russian victory at Poltava in early July 1709), with substantial losses on both sides.

5 There words probably refer to the conquest of Azov by Tsar Peter I in 1696, which consequently provided Russia access to the Azov and Black Seas. Turkey (the Ottaman Empire) was compelled to begin talks with Moscow that concluded with a favorable treaty for the latter.

${ }_{6}$ Boris Nikolaevich Yeltsin - President of the Russian Federation from 1991 to 1999. (electronic resource: http://www. yeltsincenter.ru/en/node/90 - accessed 6/9/2015)

\section{References}

Filatov, L.A. (2006). Pro Fedota-strel'tsa, udalogo molodtsa [Fedot the Musketeer, a Brave $\mathrm{Lad}]$, Moscow, Eksmo, 13-72.

Kiklevich, A.K. (2014). Dinamicheskaia lingvistika: mezhdu kodom i diskursa [Dinamic linguistics: between a code and a discourse], Kharkov, Gumanitarnyi tsentr, 444 p.

Kovtun, E. F. (2014) Russkaia futuristicheskaia kniga [Russian futuristic book], Moscow, RiP-kholding, $229 \mathrm{p}$. 
Kubriakova, E.S. (2004). Iazyk i znanie [Language and knowledge]. Moscow, Russian Academy of Sciences, Institute of Linguistics. - Moscow, Iazyki slvianskoi kul'tury [Languages of Slavic culture], $560 \mathrm{p}$.

Zemtsov, I.G. (2009). Sovetskii iazyk - entsiklopediia zhizni [The Soviet language as the encyclopedia of life], Moscow, Veche, 512 p.

\title{
Русский фольклор \\ как поэтика инференции \\ (на материале сказки Л. Филатова \\ «Про Федота-стрельца, удалого молодца»)
}

\author{
И.А. Гусейнова ${ }^{a}$, У.К. Брумфильд ${ }^{6}$ \\ а Московский государственный лингвистический университет \\ Россия, 119034, Москва, ул. Остоженка, 38 \\ ${ }^{\sigma}$ Университет Тулейн \\ США, Луизиана, Новый Орлеан
}

\begin{abstract}
В настоящей статье русский фольклор исследуется на пересечении теорий семиотики и дискурса с позиции динамической лингвистики. Русский фольклор рассматривается как семиотический код, облегчающий раскрытие дискурса во времени и пространстве и одновременно обеспечивающий передачу культурных и литературных традиций, а также консолидацию различных этносоииальных групп. Анализ поэтики умозаключений проводился на основе материалов современной русской сказки, изобилующей неоднозначностью, преодоление которой возможно посредством эмоциональных и интеллектуальных усилий читателя. Знание глобального контекста, исторических фактов и реалий дает читателю возможность, с одной стороны, детально понять фольклорные традиции, с другой стороны - понять духовную и материальную культуру русского народа - носителя фольклорного элемента.

Ключевые слова: фольклор, динамическая лингвистика, поэтика инференции, сказка, жанр, событие, поэтическое слово, стереотип, оченка.
\end{abstract}

Научная специальность: 24.00.01 - теория и история культуры. 